\title{
„DO THE UNEMPLOYED WANT TO WORK?" EMPLOYEE ABILITY AND THE WILLINGNESS OF THE UNEMPLOYED
}

\author{
$J_{U D I T} \operatorname{CSOBA}^{1}$
}

\begin{abstract}
Among the numerous supposed reasons for unemployment, nowadays it is more and more frequently argued that the unemployed do not want to work. This view holds that welfare states' support systems and the motivational tools they've applied so far are ineffective, and the situation which has arisen can be handled only with coercive measures. By examining the historical, economic and social background related to this opinion, this study aims to answer the following questions: Which values and interests make up the background of the endeavors to sanction the indolence of the unemployed? Why do a substantial number of people refuse to distinguish working ability from willingness to work? How do social and economic cycles influence the public's opinion on voluntary unemployment? This paper reaches the conclusion that the thematisation of the laziness of the unemployed is always intensified during cycles of economic crises, and the problem can only be solved by making well-targeted economic decisions at the political level.
\end{abstract}

KEYwORDS unemployment, "work-hours", "work-test", "workfare" system, employee ability, willingness to work

Arguments about inspiring employment are not about laziness or diligence, but money. Nobody regards the winner of the lottery as lazy, even though he does nothing (Schroeder, 2000: 94).

The most often heard argument regarding unemployment reduction methods supports the idea of the "workfare" model. Among those who view the new labor market model as a necessity, one can detect, ever more often, the incontestable background argument that, namely, the change from the "welfare" system, which gives social support to those losing touch to

1 Judit Csoba is Head of the Department of Sociology and Social Policy at the University of Debrecen; e-mail: csoba.judit@dragon.unideb.hu 
the workfare system, which guarantees resources in proportion to work, is necessary as argued that the "unemployed do not want to work" . Vagrancy is generally emphasized by liberals and conservatives, while social democrats argue that the number of voluntary unemployed is rather small in today's society as confirmed by results from empirical analyses. In their opinion, the problem is not willingness to work, but the insufficient number of jobs and disproportionate salaries compared to performance. Therefore, their opinion goes as follows: "the unemployed cannot (no jobs available), are not able to (qualifications, health condition), or will not take a job which is not worth it, i.e. leads to a deficit (salaries which fail to cover living costs)."

In the argument regarding vagrancy and the misuse of welfare allocations, as noted above, numerous questions are mixed at the same time. Answers frequently reveal only one or two sides of the problem, and do not coherently show the attitudes of the unemployed to work in their complexity. If we want to answer the question of whether the introduction of the workfare program is really justified by the high number of voluntary unemployed and associated social loads, we have to investigate certain fundamental issues:

1. Is there individual or social responsibility behind unemployment and idleness? "Are the unemployed sinners or victims?"

2. What is the historical experience and what motivations can be found independent of time and space - behind centralization and sanctions?

3. Is work still an elementary pre-condition for human dignity or is it demotivating?

4. Where is the boundary between employee ability and employee willingness?

5. Can social and economic cycles influence opinions regarding voluntary unemployment?

\section{INDIVIDUAL AND SOCIAL RESPONSIBILITY - ARE THE UNEMPLOYED SINNERS OR VICTIMS?}

Perhaps the most interesting among the presumed reasons for unemployment - emphasized ever more frequently in the $21^{\text {st }}$ century - is that people (i.e., the unemployed) do not want to work. The primary argument is laziness. Poor and unemployed people are themselves also responsible for the situation as they are fundamentally lazy. It is hard to help them.

2 Regarding the determination of "welfare" and "workfare" models and the specifics of their operation see: Bernstein, J. 1997, Deacon, A. 1996, Evans, P. 1995, Gilbert, N. 2005, Jessop, B. 1993, Mead, L. 1997, Solow, R. 1998, Torfing, J: 1999. 
The idea of laziness and associated vagrancy appears in the early stages of regulations in several countries. The English (1536) and French (1556) instituted "poor acts" to deal with the issue in the sixteenth century, and similar sanctions and regulations were also introduced later. Among these, the "Poor Law Amendment Act" from Britain can be highlighted from which the terms "deserving" and "desperate" poverty appear. As early as 1834, the aim was to maintain work houses for the unemployed so that they would inspire workers to obtain their income in the primary labor market. Not only were moral considerations behind the act, but practical ones were considered as well: there were fewer places in the work house than the number of poor registered at that time. To solve the problem, authorities at that time developed a willingness-to-work test "outside office" in order to see whether the "client" wanting help "generated" unemployment or not (Standing 1999).

This procedure was modified only in the beginning of the twentieth century, when municipal relief works were established, and the "Unemployed Workmen Act" of 1905, "regulating the employment of the unemployed", was accepted. This act called for the investigation of not only whether the unemployed "behaved well" or conscientiously searched for a job, but whether they were co-operating to gain welfare allocations and considering other means of help (e.g., financial allocations, services). The most characteristic task of the 1905 act was to guide indigents towards the life of work and to reduce their reliance on social support or to curtail their intent to do so. "Control regarding laziness is necessary", considered the decision makers of that time, "even if there are not enough jobs for motivated employees". The ability to take a job, however, has to be maintained in people, as they are liable to get used to not working and "living on the bread of the state". "Laziness", according to these opinions, "bursts from the nature of man".

Alexis de Tocqueville stated in 1835 that pauperism was the direct consequence of charity, as man has an intrinsic characteristic: laziness (Toqueville 1997). If Tocqueville was right and laziness is a natural human characteristic, then it is also true that unemployment is inherited genetically. It is like a disease for which a remedy has not yet been invented.

If there is any truth in the "genetically encoded laziness" argument, then it has to be noted that forcing lazy people to work will be useless in changing human nature. Only temporary results can be achieved, as human nature will always return to its natural limits. In order to operate society and economy, therefore, organizing workfare-type programs could be regarded as a necessity, in order to force human nature to change to ensure our survival through forcing man, a non-reasoning creature, to accept common-sense arguments. If the above mentioned discussion is true, then nature has produced a very strange creature 
by installing the gene of "laziness" into "humans", as this gene reduces selfpreservation, race preservation, and the ability of other important genes to function. Others justify the idea of workfare-type programs not through genetic arguments regarding the inheritance of laziness through generations, but through analyses of social learning and models of living together.

The term "pathological unemployment" was coined in 1992 by someone who described poverty in the United States as a behavior problem of the poor. Besides the numerous other reasons influencing the development of poverty, many scientists believe that behavior is the most important. Hawkesworth thinks that the behavior of the poor is not determined by genetics but by subculture ${ }^{3}$ (Hawkesworth 1992).

The most extreme vision of "pathological unemployment" is given by Haspers, who states that unemployed persons who receive support and support services are "moral cannibals" who think they have the right to the soul, productive energy, and time of other people, and they can only sustain their lives by relying on the income of others (Govier 1992).

On the contrary, Marx believed that the essence of human nature was activity, and that productive and creative work is, by necessity, good. Moreover, this rational and creative activity separates us from animals. Work performed by the modern worker, however, is not creative, but machine-like, monotonous, and boring. The goal and direction of the activity is not set by the worker, and the results do not accrue to them. As a consequence, workers become estranged from their work - thus in such circumstances, work cannot lead to self-realization (Marx 1967). Workers regard escape from alienating work as natural; similarly, Aristotle stated that such jobs are more suitable for slaves or at least they can be forced to work most effectively (Arendt 1999).

We can conclude from the views above that laziness comes not from human nature, but rather that as a result of social and economic factors, the unemployed abandon activities that do not require them to be rational and creative creatures.

The cause of unemployment therefore lies not at the individual level, but it is rather the result of the relationship between system-level factors that exceed the competency of the individual. Social democrats point to globalization, demographic problems (especially ageing), the increasing force of performance,

3 Various problems regarding biological arguments arose: If men are lazy based on their nature, why is it present only in a certain segment of employees - the lower class? How do upper-class workers manage to avoid this genetically determining factor? As a result of welfare reforms introduced in the United States in 1996, for example, single mothers were targeted as needing to get back to work. Why was it thought that it was only they that were lazy? Why isn't it compulsory for married women raising children to work? Why are women who live outside of marriage often considered lazy? 
a formal economy, and the market approach, which prevails over everything, as causes of unemployment. In their opinion, the unemployed are victims of this field of force. According to Deacon, for example, to inspire someone to work or seek a job is like telling him to dive into a pool that is lacking water (Deacon 1996). The continuous narrowing of work assets and the "drying out of the pool" of wage-work in western European societies enable us to draw several conclusions. On the one hand, wage-work crises involving the use of workers as reproductive and not as creative creatures presents a chance for the re-organization of the society of work. The class of owners whose wealth is due to wage-work is not enthusiastic about this and tries hard to conserve the current situation. On the other hand, a significant number of the workers released from wage-work are not capable of individual-orientated work and selfrealization. Thus, they are excluded from the newly forming worlds of work. Welfare states try to integrate these latter groups and to provide them a living during transitional time periods. The method these states apply significantly influences successful integration. Welfare societies were not always able to control the transformations in the world of work, which started in the 1980s and accelerated in the 1990s. Aims, fairness, extent, length, form, and the motivating force of passive support became issues of debate. Is this inspiring enough and can a balance between labor-market income and welfare allocations be found? Is there a way of developing economic regulations that enables the admittance of people midway through the transformation process in the primary labor market, and to what extent can the state act as regulator in economic matters, or to what extent will profit-maximizing interests gain dominance in economic and labor market policy? These questions await replies, and answers are apparently urgent as limited possibilities in the economy highlight the importance of labor-market costs even more. Within this question, the cost of labor is the primary factor. To maintain profits, short-term interests require low labor costs; so low that current welfare allocations which provide basic living standards seem too high compared to them. Liberal politicians and those holding conservative views state that unemployment which developed in the 1990 s is the result of welfare systems operated by the welfare states themselves (Schroeder 2000). Extensive statistical data are used to justify this view; for example, the continuous increase in social costs in Europe in the past two and a half decades correlates with a simultaneous increase in unemployment.

While social costs remained within $18 \%$ of GDP in 1970, they increased up to $24.4 \%$ by 1980 and reached $26 \%$ in 1991 (Taylor-Gooby 1996, 117).

This view is shared by Novak as well, who talks about lavish states. In his opinion, the support system of welfare states is in no way sustainable in its current form. Apart from financial barriers, a greater problem is presented in 
that a generation is raised - with the support of the system which no longer believes in independence, hard work, and self-realisation. The welfare state corrupts all of us (Novak 1996, 21).

Any of the examined factors - genetically-encoded laziness, sub-culturally developed and inherited behavior, or the over-support of the welfare state are considered the liberal reply to current challenges to direct former wage workers towards the labor market. The workfare program exacts a great price from the lower classes: offer more energy - in an even more dependent situation in regard to the economy and labor-market - for a lower living standard, in order to achieve sustainable development (e.g., sustainable profit). The disproportionate sharing of the social costs of economic transitions, not surprisingly, generates resistance from employees. The question regarding the conditions above therefore remains: Are the unemployed sinners or victims? The answer generally depends on one's point of view (in a given case political or economic).

\section{STRENGTHENING THE RULE OF WAGE WORKER STATUS AND SUBJUGATION}

The continued policing of the poor from an early modern age, and the regulations concerning them in the eighteenth and nineteenth centuries aim not only to deter the poor from taking social allocations illegally, but also to re-organize the wage-work constraint system and to strengthen the norm of the work-and-food connection ("who does not work should not eat") among people in lower-class groups (Vobruba 1990).

This is justified by the common opinion (derived from numerous international studies) that policing the poor is not of much use. Income from the control of illegal welfare allocation-taking cannot cover the cost of the bureaucratic system which performs controlling. If we want to strengthen budget against cheaters, then much higher income could be expected from the stricter control of tax than from strengthening sanctions against social support cheaters (Cook 1989, Cooper 1997) ${ }^{4}$.

Between 1983 and 1989 at Bremen University, a seven-year-long longitudinal analysis was performed on the issue of whether men generally forbear work or not, and whether people with the ability to cheat on the system of welfare

4 Similar views are held by others; e.g., Katalin Gönczöl in Hungary, in her publication studying the relationship between poverty and criminality. 
allocations do or not. Results showed that only $1.3 \%$ of the individuals studied showed a refusal to work, as defined in the hypothesis. The majority of presumably shirker people were unable to carry out the activities offered by society. Similar results were obtained in 1994 through other research at the Martin Luther University in East Germany. These studies fundamentally refute the fact, emphasized ever more frequently by politicians, that the unemployed are basically vagrants. Chancellor Kohl, however, in one of his speeches in 1995, called Germany a "collective leisure park", suggesting that large social groups withdraw from socially useful and necessary valueproducing activities (Schroeder 2000, 102).

It is true that for those supported by social allocations, only communityoriented tasks are given from the mentioned socially-useful and valueproducing activities; neither respected work nor income of real market value is offered. Local governments themselves, which organize these activities state that labor market opportunities for the unemployed are hardly improved at all by these tasks. The organization of public employment, however, will remain independent of parties - state a few scientists. According to them, facts justify that the hard labor required from those receiving social support is not politics-dependent. It is a generally necessary tool in binding society through concentrating on wage-work, together, and strengthening its normative criteria (Vobruba 1990, Mead 1992, Jordan 1996, Lee 1997).

The consequence of the logic of social policy based on wage-work is that the unemployed have to prove their willingness to work and their inability to get a job simultaneously. Increasing control of this is one of the possible future views.

This is called "new paternalism" by Mead in which the state requires the poor to behave in an obligatory way as is adequate for the interests of society and the economy. Putting common interests before the private interests of the individual may create controversies. Therefore, the state takes forceful measures by regulating welfare systems so that those of working age will work or study if they want to receive the support of society (allocations). "New paternalism" means close supervision by the state of the poor and the helpless in order to ensure the activity of social groups who lagged behind as cheap labor and to aid the development of group self support, thus relieving the states' welfare budgets (Mead 1997). Owners, therefore, may count on maximum independence while wage workers may count on maximum subjugation in this new system. The two extremities - either unlimited independence or maximum control - threaten the fundaments of social solidarity and constitutionality. As if not the same rights could apply to all citizens! As a consequence, the threat arises that the differentiation of law according to social structure may develop (Standing 1999). 
The attainment of profit requires cheap wage workers. Cheap wage workers are required, and in almost unlimited numbers. Lower-class groups, therefore, have to work. The state's "new paternalism" guarantees the strengthening of the rules of wage-work, otherwise its survival is not provided - in a grotesque way, neither that of the unemployed nor that of the state. Income from economic activity gets to the state in multiple ways. Thus, it is relatively easy for the state to change its perspective from primarily welfare-supporting to workfare-performing.

\title{
3. THE RELATIONSHIP BETWEEN WORK AND HUMAN DIGNITY, I.E. DEMOTIVATING FORCES
}

\author{
„, They pretend to pay us \\ and we pretend to work." \\ (Fukuyama 1992: 11)
}

The guarantee of the right to work is included in constitutions as a separate chapter in many countries, and citizens should take responsibility for the formation of their own life with this guarantee in mind - this is how the guarantee is regarded. Reasonable freedoms and freedom of choice are also included in this. Thus we can state that the law doesn't only involve forceful measures.

According to Dahrendorf, work is a market contract while citizenship is a social contract. The moment when work turns out not to be an option for selfrealization and shaping our own lives, but an obligation, it loses its voluntary character, and many try to shirk out of it - just like any other obligation (Standing 1999).

In order to prevent this, the state devised numerous coercive and controlling elements that aim to manage the adequate fulfillment of citizens' duties towards themselves and society. To control this, for example, certain employment forms are introduced that aim to restrict employment willingness. Short-term employment programs organized by state and local governments ("public work") also belong to this group. These employment possibilities are frequently rejected by the unemployed, as they precisely feel how they are controlled via the nature of this work. While rejecting such work, however, they refer not to this feeling, but to the fact that it would limit them in searching for long-term jobs with real market conditions. Thus, complete "game situations" develop where both parties play their role. The state coerces and employees shirk out of their obligations. Game theories and other social psychological experiments have proved that the way to get out of the game is not through greater coercion. 
A good many think that this form of work goes against civil rights freedoms and have taken to giving it a new name which falls between workfare and welfare: "slavefare" (Beharell 1992, 115).

Forcing some to work creates another fundamental problem. If jobs are created with only the primary aim of controlling employment willingness, then work prestige is going to be significantly reduced. If this is done, it will threaten the framework of social politics that is based on wage-work. Underrating wage-work also raises the question of how a devalued distribution mechanism, valueless from social point of view, is set to be the primary measure of distributing social goods (Vobruba 1990).

Despite all these points, the current view held is that the state has the right to force its citizens to work. "Modern slavery" (slavefare) is not new. History has revealed numerous times that the stronger central subjugation is, the stronger the efforts to escape will be. As a response, central power has had to be strengthened, to the extent of dictatorship.

Force is not only applied by the state from above, but might come directly from below, from the world of work. With the withdrawal of the state, market forces apply. Apart from a strong state, an overly-weakened state also holds enormous risks regarding the world of work (Ferge 1997).

The new form of labor-market termed generally as workfare started at its most basic level in American society. The possibility of new, complete employment is associated with a widening range of services and an increasing number of workers employed in them. This is why this process is called "Americanizing" the labor-market. There are many critics of this process, however. The first group calls attention to the segmented nature of the new labor-market, and to the increase - at a seemingly unbearable rate for those who have been socialized in European societies - of social distances.

"It seems that the range of personal services increases intensely only in those countries where social distances are very large" (Schroeder 2000, 151). General demand for the work of those providing these services to earn a living only develops when upper-class people earn significantly more than, for example, their household staff.

Some call attention to the formation and dynamic development of a "society of slaves" in relation to the American and English economic and employment programs. Others describe currently ongoing processes as "re-feudalism" of society and economy (Thie 1997).

According to Clement, the last "boom industry" in the English economy took place at a time when society was separated and "slaves" appeared in households (Clement 1996). 
Expanding employment through cheap employment possibilities runs up against fundamental moral barriers in the majority of European countries. Not only is the return of "slavery" (as a social class of people) criticized, but income earned by servants is regarded to be disgracefully low compared to the work performed and the servants' human needs. A fundamental condition of this service is that servants have to have adequately low wages. As a result, workers in this sector live permanently on the edges of poverty.

The first signs of the phenomenon began showing up in the 1960s. Deppe was already calling attention to threats at that time. He talks about an evolving "servant-proletariat". At first the warning referred to the fact that the sector change cannot be avoided. The majority of laborers have to move from the industrial to the service sector. The new sector, however, presents hardly any better conditions than the industrial sector did for its own employees in the eighteenth and nineteenth century when it was born. The situation of the workers in the services industry is comparable to those during early industrialization regarding organization, protection, and negotiation (Deppe 1966). Gorz also protested against the phenomenon. He describes the evolving labor market in Europe following changes in employment and working right regulations in the early 1990s as the "colonization of the world of work". He compares the expected result to South African society (Gorz 1994). Albert uses the term "economic apartheid" in describing the developing process (Albert 1993, 74).

The separation of the society, the development of social status in the framework of this new type of employment, continuous subjugation, and an increasing opposition to the society of work are worth noticing even if we talk little about them. There are some who think too little. "No one calls out against it! No one revolts! How will a group which continuously serves the other, without the hope of breaking through, be effected (Schroeder 2000, 154)?”

\section{EMPLOYEE ABILITY AND WILLINGNESS}

Employee ability and willingness are used frequently as synonyms in political rhetoric. Numerous arguments are made that the unemployed and social beneficiaries are voluntarily unemployed and don't live up to their social obligations. They take no part in producing social values, and much worse for the state, they pay neither tax nor contributions; on the contrary, they require social support. They take advantage of opportunities provided by the society and prey upon the rest. Arguments, however, are seldom based on facts, but rather on political goals: burdens on the central budget have to be reduced, the number of tax payers has to be increased, and welfare costs have to be 
reduced. Investigations into the truth of statements like those above, as well as questions regarding the ratio of voluntary unemployment are rare. Results and empirical data from the few investigations all contradict these statements.

Political rhetoric seldom differentiates between ability and willingness, as it is much easier to communicate the apparent fact that someone does not work because they are unwilling to do so. It is simpler to emphasize individual reasons and responsibilities and to solve the problem in the most seemingly simple way: by forcing the unemployed to work. In the case of a lack of ability, however, coercion provides no solution, and actually leads to the opposite of the effect intended: recognizing those who lack ability raises the question of social responsibility. Replacing or changing abilities are costly and long-lasting processes, whereas saving money and the reduction of state costs are behind the whole "political common talk" and "public opinion".

The willingness of citizens to work is apparent in numerous cases. In adapting to the world of work, however, they face numerous barriers.

\section{"The exclusion of the excluded"}

Offices are not equipped to employ mentally disabled people. While people who are disabled in terms of vision, hearing or mobility may find jobs if they are very assiduous, this group is in an almost hopeless situation.

\section{"Missing abilities"}

The acquisition of missing abilities (qualification, computer skills, and languages) is the task of the employee according to employers. Employees, however, are not able to acquire these skills from their own resources; welfare allocations do not cover these skill-acquisition costs.

\section{"Disadvantages originating from habit"}

Personality is a very complex phenomenon. It might have numerous elements that limit employee roles and make employment hopeless. A disadvantageous physical appearance ("ugliness"), slowness beyond measure, unbearable aggression, and an inability to work in a team are all characteristics that query an employee's ability rather than their willingness to work.

Employee willingness is influenced by a number of factors besides the intent of the unemployed. Situations in which people are kept unemployed can be separated into "personal" and "institutional" traps. The boundary between the two might not be too clear in certain cases, but we attempt to list examples of the situations below.

a. Personal trap situations

\section{"False self vision"}

Ideas employees have about their own employment abilities do not always reflect reality. The man in his fifties who loses his middle-management job after 
15-20 years of employment with his middle-grade qualification may not be justified in demanding a job of similar status. Similar problems face the woman in her thirties who comes back from long-term maternity leave, "forgetting" about changed technical conditions and work-organizing methods. She searches persistently for the job which matches her abilities because she thinks more training or re-training is a too big an investment with a child at home.

\section{"Self-exemption"}

Self-exemption occurs when those who do not wish to face expected difficulties in the labor market set a false diagnosis of themselves beforehand to avoid confrontation (I am too old for this, I live too far away for this, I cannot sort this out due to family duties).

"The illusions of career starters"

Young people starting careers often look for their imagined job on the basis of false illusions suggested by their schools ("Here we educate only managers, the other school trains employees!"), or they adjust their requirements to unrealistic career images and salaries suggested by mass communication media ("I won't slave for a starvation wage!").

“Altruistic careers"

The overrating of personal and social bonds frequently leads to unemployment. “"My husband would not be happy because he'd think he has to support me”, or „I would not be accepted anywhere as a mother with a small child". Further research tries to expose whether these altruistic careers are the "causes" or the "results" of unemployment as self-exemption strategies. The situations contain clear messages: "I would be unwanted in the labor market anyway, so I conceal the feeling of being unneeded and the developing situation through social obligations".

\section{"Dependent situations"}

The most frequent ones of this type are addictive disorders and homelessness, or both together. "For a decent job, a registered home is necessary and that is what I do not have". Or the characteristic vicious circle: "Until I drink I won't have a job because I drink!"

\section{b. Institutional trap situations}

\section{"Reservation wage"}

This is well-known in labor economics. If the balance of net income from work and the costs associated with the job stay below welfare allocations, the rational decision of the employee will be to remain absent from the labor market.

"Underground economy"

When earning income legally is not possible while collecting social allocations, or if the pay grade for a given position within the underground 
economy is more competitive than those of legal status, the unemployed choose the underground economy. In such cases, the individual is not absent from the labor market, but does not work within the framework of the controlled economy.

\section{"Conditioning for long-term passive allocations"}

If a series of passive allocations succeed each other (e.g., unemployment insurance allowance, unemployment support, and unemployment compensation other than regular social support for the unemployed of active age), then a passive habit develops that generally corresponds with the gradual deterioration of the individual and the gradual loss of employee willingness and ability. A typical "boiled frog" situation occurs: a frog sitting in slowly warming water which is gradually heated up to $100^{\circ} \mathrm{C}$ does not notice that it is being boiled. Similarly, the unemployed person does not notice that their deterioration due to decreasing income is so advanced that they could not break from the system even if they wanted to.

\section{"The paternalist play"}

An unrealistic image has been formed in the minds of unemployed persons over fifty years of socialism and through recent welfare programs: that it is society that is responsible for members of society and not individuals. This is the appearance of "learnt impotence" within a social group. Or it is the "fish net" problem known in the social profession. We are not used to receiving a net!

As the examples above show, there are numerous situations regarding employee willingness when unemployment is the result of rational decisions. In similar situations, those who created the regulations would not act any differently. In these cases, the question arises as to whether lack of employee willingness is of individual responsibility or a result of institutional trap situations; without the elimination of the latter, no real solution to the problem is possible. Solutions which affect the system, however, require social responsibility and cost mobilization. This is not in the interest of those interest groups that thematize voluntary unemployment. The financing of costs related to the resulting situation or the solution, through the system, are both undesirable, and consequently they are loaded onto the losers (Daly 1997, Gilbert 2005).

Welfare allocations tied to certain conditions in the workfare model are regarded as improvements to traditional public employment, as the latter involved no or only minimal possibilities for improving skills, training, or recovering abilities. The primary aim was to filter and coerce. In the workfare model, the possibility of entering programs which improve or maintain employees' abilities is given. Only a few questions remain: Is the workfare society organized for short-term or long-term interests? Will ability or 
employee willingness be the focus of the programs? If short-term interests succeed, how is it possible to ensure the success of a long-term individual improvement program for those who are unemployed for a long time without basic qualification and lacking abilities, but who are motivated to work?

\section{ECONOMIC REPRESSION AND IDLENESS}

The validity of the above questions is also justified in that the "misuse of allocations from the welfare state" argument is always emphasized more during times of high unemployment. However, it is far from sure that this high rate is the result of many individuals misusing allocations from the welfare state. Perhaps the labor market was significantly limited earlier, and the unemployed missed out on the market, but the state communicated it differently. Looking for individual responsibility has always been popular during hard economic times. Obviously there were unemployed persons and vagrants when a dynamic economy employed a higher rate of labor, but no one talked about these groups then (Vobruba 1990).

"Our society provides the right to laziness for nobody," said Federal Chancellor Schröder in May 2001, triggering arguments in the media about the laziness of the unemployed. Lazy, pretend job seekers stowaways, and similar terms were given in the media. Provoking the laziness of the unemployed was an excellent way of releasing pressure from an otherwise stressful social atmosphere. This argument about the laziness of the unemployed, however, has not been unique over time.

As a matter of fact, these arguments are nothing else but labor market reflex automatism. Any time the government is two years away from an election and economic boom somewhat slows, it rings the alarm-bell of laziness even though there are no apparent signs of the unemployed being more lazy in the second year than in the year before.

Since the 1970 s - according to analysts - four great "laziness"-argument periods can be identified. The first went on in the middle of the 1970s (starting in 1975), due to the economic shock caused by the oil crisis. The second period was at its height in 1981, when Dr. Riedl (CDU/CSU), a Member of Parliament at that time, called attention to the subject: “...such a palanquin has developed in which the unemployed have transported themselves on the money of citizens paying tax and social insurance contributions from demonstration to demonstration, from house-seizing to house-seizing, from Molotov cocktail party to Molotov cocktail party, and finally to a rest from all these to Mallorca or elsewhere (Schmidt-Osmiansky, 2001: 5). 
The third argument period was sharp in 1993 as well. All arguments were widely published by the media with colorful and realistic examples. "The fourth laziness argument is currently going on", wrote Schmidt at the turn of the millennia. The consequence of this a few years later was the series of Hartz reforms, the waves of which have reached Hungary as well in the last few years.

Careful examiners may notice four points in all of the laziness debates that fundamentally characterize the process:

a.

- All of the arguments took place during politically-threatening times or periods of high unemployment,

- The first three were especially associated with the three major economic recession periods that resulted in striking increases in unemployment rates each time. The current ongoing argument is probably caused by the fact that welfare costs have exceeded the limits of the state budget and insurance funds.

b.

- All arguments were supported by wide public-opinion research in which people stated that the unemployed do not want to work.

c.

- Debates in all of the cases were timed 1- 1.5 years before the upcoming elections.

d.

- These arguments resulted in reduced support periods, support levels, and entitlement-criteria aggravation each time.

It is clear from the reasons above that most of these arguments are actually, or rather, have been associated, not with the potentially faulty behavior of the unemployed, but with the results of political manipulation. The correlation between the derogatory public opinion of the unemployed and approaching elections is striking. Politicians regard the unemployed and those missing from the world of work as scapegoats due to increasing social dissatisfaction, and use them to mask decisions and changes of political orientation about the labor market and employment policy.

In Germany, for example, 3.5 million unemployed people can compete for only 1.5 million jobs, and many of the advertised jobs cannot be filled by the registered unemployed. Hungarian data are even worse. Most unemployed who have been waiting for a job for over two years believe that the best further training for them would be a decent (i.e., appropriate for their qualification, paid at social average, longer than one year) job. 
"Raising the limit for indigents" and re-moralizing the unemployed are not the most adequate ways of creating jobs. Despite all this, the widespread international experience of sanctioning that has been developed since the turn of the millennia appears to justify the fact that politicians believe in the efficacy of punishment. The suspension of support - e.g., by official judges - can be initiated at any time in most European countries. The suspension of unemployment support or the period of welfare allocations varies by country: e.g., one week in Denmark, twelve weeks in Germany, 26 weeks in New Zealand, and 52 weeks in Belgium. In Spain, the right to unemployment support terminates immediately when the recipient rejects the first active measure. In Japan, if no agreement is concluded for a job, then the right to support does not terminate but benefits are made payable later. In Denmark, they react similarly to the Spanish, when, for example, training is rejected. However, this is only effective after one year of support, in the activating phase. Not only are the length and force of sanctions interesting in different countries, but the rate of affected groups is also informative in applied practice. In Germany, the suspension of unemployment support affects only $1.1 \%$ of the target group. This ratio is $60 \%$ in the United States, and $40 \%$ in Switzerland. Australia, Great Britain, and Belgium punish mainly administrative omissions by suspending support. Such omissions include, for example: a failure to register any short-term work, a changed residential address, or an absence from a fixed discussion. Most of the unemployed in the United States and Switzerland are punished by suspension because their search for a job was not intense enough. In Germany, Denmark, and Norway, suspension is generally caused by the rejection of active labor-market measures. Due to inadequate job search intensity, a one-week suspension of support is given in the United States. This affects a large proportion of the target group, but they survive it relatively easily. In Australia, if the unemployed person does not search for jobs intensely enough, support is reduced by $18 \%$ for 26 weeks. This is a major cut. In Belgium, the rate of suspended unemployed is very low $(0.02 \%)$, as the punishment is very severe: it may extend over 26-52 weeks (SchmidtOschmiansky 2001, Ughetto 2002, Solga 2002, Bonoli-Sarfati 2004).

What are the consequences of the "laziness" debate when all things are considered?

- Neither the problem, nor its management are new,

- it has kept returning for centuries, mostly in unchanged contexts, and very much with similarly applied measures: sanctions, hard labor, moralization, and with an emphasis on individual responsibility in spite of analysis and economic problem-solving, 
- there is always an emphasis on individual responsibility,

- it returns in well-defined political situations and forms part of the legitimacy plays of governments in power,

- it is the result of the imperfect operation of the labor market and social and political strategies that deal with it inadequately,

- unemployment is never solved by coercion,

- the unemployment rate can be influenced effectively only by political economic decisions,

- it is an economic, financial, and wage-related political issue that must be handled through complex means,

- during periods of high unemployment, jobs are missed more than employee willingness,

- the labor market and welfare system (if there is any) are overloaded due to unsolved economic problems; their strength and competence are exceeded by the force of obligatory actions.

In taking into consideration of all these aspects, many of the experts ask, "What do we need?" What is needed is such a policy - comes the reply that enables one and gives one encouragement, and not one which questions the willingness of the employee and punishes and limits them. It is true that the right to laziness is not given to man living in society, but the right could have been given to a life providing human dignity, to a life of decent income, of greater freedom in the world of work and during one's career as an employee. In conclusion, we can state that based on the experience of past centuries, unemployment is mostly not the result of employee willingness (or the lack of it), but the cyclical crises of economy and associated employee "inability".

\section{REFERENCES}

Albert, M.(1993), Capitalism against Capitalism, London, Whurr Publishers Arendt, H. (1999), Vita activa, Zürich, Pieper

Beharell, A. (1992), Unemployment and Job creation, London, Macmillan

Bernstein, J. (1997), Welfare Reform and the Low-wage Labour Market. Employment, Wages and Wage Policies, Washington, D.C. Economic Policy Institute

Bonoli, G.-Sarfati, H. (2002), “Conclusions: the Policy Implications of Changing Labour Market - Social Protection Relationship", in:Sarfati, H.- Bonoli, G. ed., Labour Market and Social Protection Reform in International Perspective, Hamphsire, Asghate, pp.453-487.

Clement, M. (1996), "Housing and Community Care", in:Richards, M ed., Community Care for Older People: Rights. Remedies and Finances London, Jordans 
Cook, D. (1989), Rich Law, Poor Law-Differential Response to Tax and Supplementary Benefit Fraud, Manchester, Open University Press

Cooper, G. (1997), "Housing Benefit Fraud Hits 1bn Pounds", The Independent, Vol.11, No .7.29, pp. 7.

Daly, M. (1997),"Welfare states under pressure: cash benefits in European welfare states over the last ten years", Journal of European Social Policy Vol. 7, No. 5, pp.128-146.

Deacon, A. (1996), "Welfare and Character", in: Deacon, A ed.: Steakholder Welfare London, IEA Health and Welfare Unit pp.60-74.

Deppe, F.(1966) "Arbeitslosigkeit, Wohlfahrtsstaat und Gewerkschaften in der EU", in.: Sozialismus Supplement, Vol. 23, No. 2, pp. 1-21.

Evans, P.(1995), "Linking welfare to jobs: workfare, Canadian style", in: Sayeed, A. ed., Workfare: Does it work? Is it fair? Montreal, Institute for Research on Public Policy

Ferge, Zs. (1997), "És mi lesz, ha nem lesz? Az állam és a civilizációs folyamat”..(And what if there will not be? The state and the civilization process) in: Gombár, Cs.Hankiss, E.- Lengyel, L. eds., És mi lesz, ha nem lesz? Tanulmányok az államról a század végén (And what if there will not be? Publications regarding the state at the end of the century), Budapest, Korridor Political Research Centre- Helikon Press

Fukuyama, F. (1992), The End of History and the Last Man London, Penguin Books

Gilbert, N. (2005), "Protection to Activation: The Apotheosis of Work", in.: Saunders, P. Welfare to work in practice: social security and participation in economic and social life. Aldershot, Ashgate, pp. 9-23.

Gorz, A.(1994), Kritik der ökonomischen Vernunft, Hamburg, Rotbuch Verlag

Govier, T. (1992), "The Right to Eat and the Duty to Work", in: Mappes T.A.- Zemboty J.S. ed., Social-Ethics-Morality and Social Policy, New-York, Mc Graw - Hill, pp. 372-383.

Hawkesworth, M. 1992), "Workfare and the Imposition of Discipline”, in: Mappes T.A.- Zemboty J.S. ed., Social-Ethics-Morality and Social Policy, New York, Mc Graw - Hill, pp. 387-394.

Jessop, B.(1993), "Towards a Schumpeterian workfare state? Preliminary remarks on post-Fordist political economy", Studies in Political Economy, No. 40, pp.7-39.

Jordan, B.(1996), A theory of poverty and social exclusion, Cambridge, Polity Press

Lee, E.(1997), "Is full employment still desirable and feasible?", Economic and Industrial Democracy, Vol. 18, No. 1 February, pp. 35-54.

Marx, K. (1967), A Töke, Karl Marx és Friedrich Engels művei (The Capital. Works of Karl Marx and Friedrich Engels), Vol. 23-25. Budapest, Kossuth Press

Mead, L. (1997), "From welfare to workfare: Lesson from America", Institute of Economic Affairs

Mead, L. (1992), The New Politics of Poverty: The non-Working Poor in Amerika, New York, Basic Books

Novak, K (1996), “The Tales from the Wasteland”, Channel 4 No. 05/06/1996.5-6. pp.21.

Rifkin, J.(1995), The End of Work, New York, Penguin 
Schmidt, S.-Oschmiansky, F.-Kull, S.(2001), Faule Arbeitslose?, WZB Mitteilungen, No.9. pp. 5-10.

Schroeder, D. (2000), Work Incentives and Welfare Provision The"Pathological" theory of Unemployment, Averbury Series in Philosophy, Burlington, Ashgate

Solga, H. (2002), “'Stigmatisation by Negative Selection': Explaining less Educated People's Decreasing Employment Opportunities", European Sociological Review No.18, pp.159-179 Oxford University Press

Solow, R.(1998), Work and welfare, Princenton, Princeton University Press

Standing, G.(1999), Global Labour Flexibility Seeking Distributive Justice New York, McMillan Press Ltd,.

Taylor-Gooby, K (1996), "Paying for Welfare: The View from Europe”, The Political Quartarley, Vol. 67 No.2. pp.116-126.

Thie, H. (1997), "Die Schatten eines gepriesenen Vorbilds", Das Parlament, Vol. 47, No. 36, 29/08.

Toqueville, A.(1997), Memoir on pauperism, London, IEA Health and Welfare Unit

Torfing, J. (1999), "Workfare with welfare: recent reforms in the Danish welfare state", Journal of European Social Policy, Vol 1. pp.5-28.

Ughetto, P.(2002)., "Creating Service Jobs: Lesson from Extra-European Experiences”, in: Sarfati, H.- Bonoli, G. ed., Labour Market and Social Protection Reforms in International Perspective Hampshire, Asghate, pp.167-173.

Vobruba, G.(1990), Strukturwandel der Sozialpolitik Shurkamp, Frankfurt am Main, Shurkamp 